\title{
REAL OPTION ANALYSIS OF VENTURE CAPITAL INVESTMENTS
}

\author{
Alexandra Posza ${ }^{1}$ \\ Received: January 16, 2020 / Revised: February 13, 2020 / Accepted: May 7, 2020 \\ (C) Association of Economists and Managers of the Balkans, 2020
}

\begin{abstract}
Venture capital investments play an important role in the development and growth of start-up companies that are characterized by a high degree of uncertainty and growth potential, and venture capital is also one of the major sources of financing for entrepreneurial businesses. In the case of venture capital investment, staging has a huge potential, so the venture capitalists keep the right to participate in further financing rounds. The real option approach as an evaluation method provides an opportunity to evaluate this kind of investment with the help of flexibility in the case of a high degree of uncertainty. The paper puts the emphasis on the evaluation and the effectiveness of venture capital investments primarily from the aspect of real option theory tested on Hungarian venture capital cases. The paper concludes that the option-based valuation methods are more suitable for evaluating venture capital investments than others, especially the discounted cash flow method.
\end{abstract}

Keywords: Real Option Theory, Strategic Flexibility, Uncertainty.

\section{JEL Classification 016}

This paper was presented at the Fifth International Scientific-Business Conference on Leadership, Innovation, Management and Economics - LIMEN 2019 - December 12, Graz University of Technology, Austria, www.limen-conference.com

Alexandra Posza

poszaa@ktk.pte.hu

1 Department of Finance and Accounting, Faculty of Business and Economics, University of Pécs, Rákóczi Street 80. Pécs, Hungary 


\section{INTRODUCTION}

This study attempts to analyze the valuation of venture capital investments and to explore links to real option theory. Venture capital is one possible form of private equity financing (Landström, 2007; Metrick-Yasuda, 2011) and a significant financial source for innovative and high-risk startups (Cassar, 2004; Ko et al., 2011) or from another aspect for high-tech, new or young SMEs (Chotigeat et al., 1997; Gompers-Lerner, 1999). In the case of venture capital, the investor appears as a financial intermediary of a non-financial corporation (Maula, 2007), the primary reward available to the investor are the capital gains (Lorenz, 1989). Moreover, venture capital investment is not limited to ensure financial sources, but venture capital investors are also involved in running and managing the businesses. According to Karsai (2006), venture capital investors aim to promote business growth and value creation through capital provided by a multi-year special investment arrangement (incentives, advice, networking, and knowledge). Gompers and Lerner (1999), Steier and Greenwood (1995) have also argued that venture capital investors can provide young firms not only with money but also with other added value, which is expressed in the form of a strategic and supportive role and social network. (Bygrave-Timmons, 1992).

The venture capitalist's investment activity is described as a five-step sequential, systematic process according to Tyebjee-Bruno (1984), which includes investment origination, screening, valuation, structuring, and post-investment phases. Fried-Hisrich (1994) described this process in six stages, distinguishing two filtering and evaluation phases instead of structuring. It is important to emphasize that the investment can be rejected at any stage in the case of both process models. In the approach of Tyebjee-Bruno (1984), the venture capitalists first recognize an investment opportunity, and in the second step, filter potential investments, focusing primarily on those that belong to their field in terms of technology, product and market. According to Gompers (1995), venture capitalists review the business plan of their young venture at this stage. In the third evaluation phase, future returns and risks are estimated based on financial and accounting information (Wright-Robbie, 1996), and other qualitative and relevant information. The fourth stage occurs when the valuation has led to a positive outcome and venture capital investors begin the process of negotiating with the potential entrepreneur regarding the amount invested, its form, and price, and then the contract is concluded. The final phase is the post-investment activity, which is a formal representation of the company owner and coordination with the company management. In the final stage, venture capitalists help entrepreneurs find exit opportunities through acquisitions, mergers or exchanges and IPO (Lee, 2018)

The study is focusing on the valuation of venture capital investments, which is also an essential and critical part of the entire venture capital investment operating process. The assessment of venture capital investments can be divided into qualitative and quantitative approaches. In a qualitative approach to evaluating venture capital investment, Tyebjee-Bruno (1984) considers management as the most critical factor, that is followed by market growth, while Ray (1991) examines the entrepreneur's personality and experience. Kaplan-Stromberg (2000) complements Tyebjee-Bruno 's (1984) approach with corporate strategy, as well as technical competitiveness. Besides, Fried and Hisrich (1994) emphasize the viability of the project, the unity of the management team, business performance and leadership capabilities, and the likelihood of an easy exit to obtain high returns.

From a quantitative point of view, the valuation procedures that are used for the assessment of venture capital investments come to the front. Wright et al. (2004) consider the used valuation procedures and the related information that is available to venture capital companies crucial. The 
traditional venture capital valuation process involves analyzing future cash flows, stock prices and stock market performance of comparable companies, and calculating P/E (Price-to-Earnings) or P/S (Price-to-Sales) ratios (Seppä-Laamanen, 2001). According to Karsai et al. (1998), discounted cash flow (DCF) based procedures may raise valuation problems in uncertain environments. DCF methods can only handle the value determination process in a deterministic way (Takács, 2014).

When a venture capitalist invests in a sustainable and profitable company, their investment creates value for investors, entrepreneurs, and society too (Rosenbusch et al., 2013). High growth potential and the high variance potential of enterprises can be seen as drivers of economic growth by promoting and sustaining economic growth and renewal as a fundamental value generator and as a catalyst for new industrial development (Bygrave-Timmons, 1992). The venture capital financing process is continuously influenced by idiosyncratic uncertainties (Davis et al., 2004; Li, 2008; Pennings-Lint, 1997; Wang-Zhou, 2004).

Venture capital investment is, therefore, characterized by a high degree of uncertainty and, according to Seppä and Laamanen (2001), can be divided into options. Risk and uncertainty make it difficult for venture capitalists to identify innovative startups' sustainable and profitable investment opportunities (Gerasymenko-Arthurs, 2014; Lukas et al., 2016). The entrepreneurial, market, and economic uncertainty can influence venture capitalists to become risk-averse to innovative startups (Smith-Cordina, 2014). Option theory can provide an answer to the valuation challenges of venture capital investments with high growth potential and uncertainty. This study seeks answers to research questions on whether and how the real-option theory provides an appropriate framework for evaluating venture capital investment.

\section{LITERATURE REVIEW OF REAL OPTIONS AND VENTURE CAPITAL}

A real option is ,an investment in physical assets, human resources, and organizational capabilities that respond to future potential events" (Kogut-Kulatilaka 2001, p. 3). The real options are similar to financial options because these give also a right but not obligation to buy or sell the underlying asset for a prescribed price at a predetermined time (Copeland-Antikarov, 2001). In the real option approach, uncertainty has value due to the ability of managers to actively manage uncertain projects (Boyer et al., 2003; Herder et al., 2011), that is, to incorporate flexibility into the managerial toolbox.

According to Hommel-Pritsch (1999) and Pritsch (2000), the real option theory can be interpreted on two levels, which also appears in their real option management model, that it manifests itself as a tool or qualitative evaluation method of the option. Triantis-Borison (2001) has a similar idea since they believe that the use of real options can be divided into three groups, such as the way of thinking, the analytical tool, and the organizational process. In the first case, it is primarily viewed as a language that qualitatively frames decision-making problems. In the second case, the real option valuation procedures are used to evaluate projects, and the third option is the organizational process, in which it plays a role as a management tool that defines and exploits strategic options as part of a broader process.

Real option types provide a framework for analyzing real options, which help to operationalize and support decision thinking. Trigeorgis (1996) differentiated the option to defer, option to reject, option to alter (expand or shutdown), option to switch, growth option, and compound real options. The value of the option to defer is derived from providing the company with the ability to shift the investment decision over time to obtain new information that may remedy or reduce 
existing uncertainty (Rózsa, 2004). The option to reject is the abandonment of all or part of the project and the permanent liquidation of the investment if the market situation turns unfavorable. According to Huang-Chou (2006), the real option of dropping an investment project is being protected against future operating losses. Option to switch (shutdown and restart options) allow market management to decide to stop production in adverse market conditions but do not rule out the possibility of a restart (Csapi, 2018). Option to alter includes two options, including the option to expand and option to contract that can be used in the event of a permanent and significant improvement or deterioration in market conditions. Growth options are similar to the option to expand, but the difference lies in their place within the corporate strategy. Growth options provide project-wide flexibility, while expansion and staging options appear as project-wide options. In the case of staging (time-to-build) option, project managers can split investment projects into phases and then transfer the experience from the earlier periods to the later phases. Each stage of the project is evaluated, and management can decide whether to continue or reject the project (Scialdone, 2007).

For large investment projects, staging provides management the right to design the following project phases, depending on how uncertain future revenues and costs from project development may be. The project is implemented in phases, thus eliminating the technical uncertainty as well as the uncertainty of demand for products or services included in the project (Adetunji-Owolabi, 2016). The option price or premium, in the form of first-stage development costs, gives the right to incur development costs in the next stage. The strike price is the development cost of the subsequent phases, while the expiration date is the time at which the staging option is incorporated into the project and the date of the call of the staging option. Staging options are valuable for infrastructure projects (ports, power plants, water utilities, telecommunications, etc.) and R\&D in intensive industries, such as the pharmaceutical industry, biotechnology, and venture capital investment (Majd-Pindyck, 1987; Trigeorgis, 1993; Rodrigues-Armada, 2007). The last type of real option, the compounded real option, involves the real options described above, and their combination. Sahlman (1993) identified three types of options from the foregoing that are inherent in venture capital investment, such as the option to reject, the project revaluation option (staging option), and the capital increase option (growth option).

Venture capital investments are characterized by a high degree of uncertainty and risk, which can also be traced back to the provision of financing to innovative, early-stage companies. Real option theory offers a way to address this by providing venture capital investors with professional experience through their active role in decision-making (Carvalho et al., 2005). Venture capital projects are characterized by significant market uncertainty (Bygrave et al., 1989). However, these uncertainties allow venture capital investors to postpone or delay their investments, i.e. to apply real option logic (Trigeorgis, 1996).

Determining how to make a successful decision in a venture capital project is a complex investment problem that also arises from the characteristics of funded companies (Miltersen-Schwartz, 2002). Venture capital projects are sequential investment decisions in which the venture capital investor has to decide whether to continue investing in the project or not (exit) (Sahlman, 1990; Gompers, 1995; Gompers-Lerner, 1999, Dahiya-Ray, 2010). According to Landier (2002), staging is one way to protect an investor from risk when entrepreneurs have an exit option. Sahlman (1990) notes that regular venture capital staging is the most effective control mechanism for venture capitalists as it provides periodic reassessment. Bergemann and Hege (2005) show that the duration of funding, but not necessarily its extent, increases in later stages. Early-stage companies require periodic investments, which can be considered as a multi-phase (compounded) call option. 
The stages of venture capital investment, according to Cumming-MacIntosh (2001), are seed, startup, early-stage, expansion, acquisition, and turnaround, while Gong et al. (2006) investigate the seed, start-up, growth, expansion, bridging, and listing (exit) stages. Investments along these stages can be examined and real options can be identified. Venture capital investors have the right to choose the time and phase of the investment, i.e. they have a (call) timing (deferral), growth and staging option that allows the investment to be shifted over time. In addition, based on the information available, they have the right to suspend the project, which is a real option to reject (put option). Staged financing also provides real options for rejecting the project, which reduces the principal-agent problem too (Hsu, 2002; Hege et al., 2009). The higher frequency of milestones and funding rounds should result in a more practical application of disclaimers and, consequently, lower agency costs and better investment performance (Gompers, 1995).

\section{METHODOLOGY}

In general, the choice of the appropriate valuation method requires consideration of its conditions of application, which, in the case of real option theory, result from the examination of uncertainty, flexibility, reversibility, and exclusivity. When evaluating strategic investments with high levels of uncertainty, the use of the DCF method may result in limited or misleading values (Adler, 2000; Park-Herath, 2000; Yeo-Qiu, 2003; Pless et al., 2016). The combination of the four characteristics results in a better result for strategic investment valuation than the real option methodology, where the word better is generally meant to identify an adequate degree of value creation. Each evaluation process has both advantages and disadvantages, so it is essential to choose the method that best supports decision-making for the project.

Real option valuation procedures fall into two major analytical and numerical categories (Schulmerich, 2010). Analytical methods include closed-form models and approximation methods. Closedform models use formulas to value an option, thus simplifying the procedure (Adetunji-Owolabi, 2016), but the relationship between the valuation parameters needs to be examined (Hartmann, 2006). Analytical methods include the Black-Scholes model, which is widely used to evaluate real options. Numerical methods lead to solutions through the underlying stochastic process or partial differential equations. Frequently used methods for estimating stochastic processes are Monte Carlo simulations, binomial pricing models, and decision trees.

Willner (1995) was one of the first to model the value of startup companies, concluding that many startup companies have the characteristics of a growth option. Jägle (1999) proposes binomial pricing for the evaluation of sequential processes, and Smith-McCardle (1998) also emphasizes that decision trees are most capable of displaying the flexibility of decision making.

\subsection{Black-Scholes model}

The Black-Scholes model was a breakthrough in economics, being the first one-period model to price European options. The model is deterministic, and it does not assume the presence of stochastic elements in the variability of volatility, that is, it assumes constant volatility of returns over a short period. There are some conditions for applying the Black-Scholes model that makes it challenging to apply in practice.

The model gives the value of a European call option:

$$
c=S * N\left(d_{1}\right)-X * e^{-r t} * N\left(d_{2}\right)
$$




$$
\begin{aligned}
& d_{1}=\frac{\ln \left(\frac{S}{X}\right)+\left(r+\sigma^{2} / 2\right) T}{\sigma \sqrt{T}} \\
& d_{2}=d_{1}-\sigma \sqrt{T}
\end{aligned}
$$

where $\mathrm{c}$ is the current value of the call option, $\mathrm{S}$ is the current price of the stock (underlying asset), $\mathrm{N}\left(\mathrm{d}_{\mathrm{i}}\right)$ is the probability that the value of a randomly selected number from a set of normally distributed numbers is less than $\mathrm{d}_{\mathrm{i}} \mathrm{C}$ is the strike price of the option, $\mathrm{r}$ is the risk-free interest rate, $\mathrm{T}$ is the maturity of the option and $\sigma^{2}$ is the variance of stock (underlying asset)'s yield (Rózsa, 2007).

The similarities have already mentioned between financial options and real options. The financial option parameters described by Black and Scholes (1973) correspond to the factors of the real option theory, first summarized by Luehrman (1998), and the analogy between these two option theories is shown in Table 1.

Table 1. The analogy between financial and real options Source: Own construction according to Luehrman (1998)

\begin{tabular}{|l|c|l|}
\hline Financial option & Variable & Real option \\
\hline Stock price & $\mathrm{S}$ & Present value of project's operating assets to be acquired \\
\hline Strike rice & $\mathrm{X}$ & Expenditure required to acquire the project assets \\
\hline Time to expiration & $\mathrm{t}$ & Length of time the decision may be deferred \\
\hline Variance of returns on stock & $\boldsymbol{\sigma}$ & Riskiness of project assets \\
\hline Risk-free rate & $\mathrm{r}$ & Time value of money \\
\hline
\end{tabular}

\subsection{Binomial Pricing Model}

Cox, Ross, and Rubinstein (1979) introduced the binomial pricing model as a numerical approximation method that became widely used in European and American-type option valuation. To determine the value of options with the binomial option pricing model actually means a process of solving a decision tree (Brealey-Myers, 2005), and that estimates the value of an option at time $\mathrm{t}=0$.

This paper is focusing on how to construct a lattice for a European call option. The binomial tree uses a discrete-time framework. Aligning the branches of the tree, we count backward from the future appointment, while considering the optimal procedure at each decision nodes (Brealey-Myers, 2005).

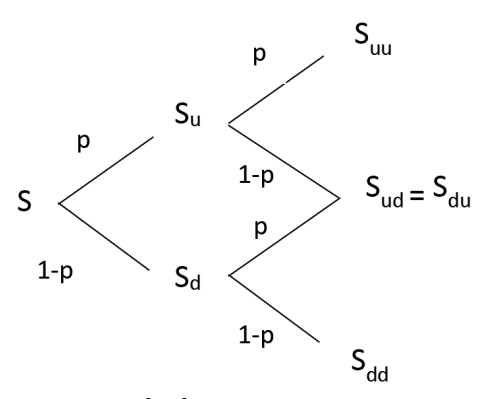

Underlying asset

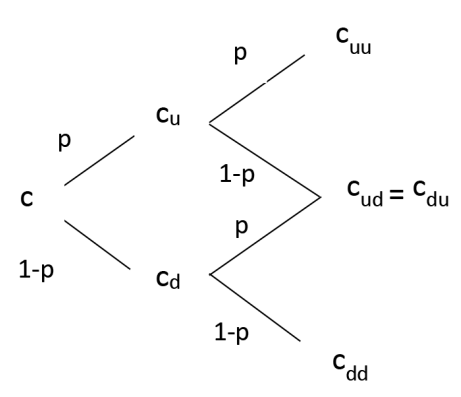

Call option

Figure 1: Two-step binomial tree

Source: own construction 
At the final node of the decision tree, the option value is equal to the intrinsic value, so in the case of a call option $\mathrm{c}=\max [\mathrm{S}-\mathrm{X} ; 0]$. The life of the option $(\mathrm{T})$ is divided into $\Delta \mathrm{t}$ discrete periods, and the price of the underlying asset (S) can make a single move, either up or down. These movements are given by $\mathrm{u}$ and $\mathrm{d}$ multiplicative parameters $(\mathrm{u}>1 ; \mathrm{d}<1)$. The probability of an upward movement is denoted by $\mathrm{p}$ and the one-period risk-free rate is nominated by $\mathrm{r}$ parameter (Breen, 1991). Figure 1 illustrates a two-step binomial tree where

$$
\begin{aligned}
& u=e^{\sigma * \sqrt{t}} \\
& d=\frac{1}{u}
\end{aligned}
$$

If the value of the underlying asset grows to $\mathrm{S}_{\mathrm{u}}$, the call option value is $\mathrm{c}_{\mathrm{u}}$, and when the underlying asset value decreases to $S_{d}$, the call option value changes to $c_{d}$. When we constructed the binomial tree of the underlying asset and the option value, we have two opportunities to calculate the option value: with the replicating portfolio and risk-neutral probability pricing.

Copeland-Antikarov (2001) assumed that the project value without option is the best unbiased estimation of the project's market value, and it serves as an underlying asset within the replicating portfolio, which means that markets are complete with option extended projects. In the case of the replicating portfolio, a synthetic option is constructed from the option and a bond. The underlying assets values replicate the payoff of the call option, that is called the hedge ratio ( $\Delta$ or option delta) that is calculated with the following formula:

$$
\Delta=\frac{c_{u}-c_{d}}{S(u-d)}
$$

In addition to this, the investor needs to put in his portfolio $\Delta$ number of underlying assets, and B invested in a risk-free bond that pays interest $\mathrm{r}\left(1+\mathrm{r}_{\mathrm{f}}\right)$.

$$
B=\frac{u * c_{d}-d * c_{u}}{r *(u-d)}
$$

The portfolio values replicate the value of the project. The present value of the call option is equal to $\mathrm{c}=\Delta \times \mathrm{S}+\mathrm{B}$ and in the next period on the upside with p probability, the call option value is equal to $\Delta \times \mathrm{S}_{\mathrm{u}}+\mathrm{r} \times \mathrm{B}$ and on the downside with $(1-\mathrm{p})$ probability $\mathrm{c}_{\mathrm{d}}=\Delta \times \mathrm{S}_{\mathrm{d}}+\mathrm{r} \times \mathrm{B}$. With the help of $\Delta$ and $\mathrm{B}$ parameters, the value of the call option can be determined. The assumption of no arbitrage situation leads to the risk-neutral valuation. In this case,

$$
q * S_{u}+(1-q) * S_{d}=S * e^{r * \Delta t}
$$

where

$$
q=\frac{e^{r * \Delta t}-d}{u-d}
$$

After the calculation of probability, the call option value can be determined by the following equation:

$$
c=\frac{q * c_{u}+(1-q) * c_{d}}{r}
$$




\section{ANALYSIS AND RESULTS}

The real option theory can be interpreted not only in theory but also in practice, which has been illustrated through a case study. Every semester, the Simonyi Business and Economic Development Center of the Faculty of Economics of the University of Pécs announces the "5LET OUTLET" idea competition, which is open to university citizens with their business ideas, and then marketable projects can be included in the Simonyi Incubation Program. In February 2017, an application-based business idea focused on networking and getting to know applied for the competition. The potential and scalability of the idea, as well as the personality and dedication of the idea host convinced the jury and the project could enter the business incubation program. During the 14week program the idea owner developed a business idea and business model with the help of a student team and a mentor. In this phase, growth opportunities led the idea creator to shape the concept, while uncertainties (technology, market, region-specific) about the project also presented themselves. During mentoring and counseling, they sought answers to address the uncertainties, for which the idea host conducted environmental, market and industry analysis with the brainstorming team. The team played a significant role in the idea formation and progress during the incubation process. In the incubation program, the idea host had to invest the time, energy, and private capital needed to develop the idea to achieve development and growth. In order to obtain a source of funding, the business idea had to reach a stage that would convince capital providers that the concept had a viable and promising future. For development, it became clear that capital involvement was needed but thanks to the brainstorming opportunity the solution was found through the incubation program. The company was founded in February 2018, and after the viability of the project had been examined by a venture capital investor, the company first received a venture capital investment of 9,000,000 HUF, and a year later, another sum of 30,000,000 HUF. In this case study, a venture capital investment of 39,000,000 HUF is valued. Venture capital investment is thus a two-tier investment that can be interpreted as a compounded call option. However, the growth plans of the company are surrounded by considerable uncertainty the project carries the potential for postponement and staging, which means with enough managerial flexibility, the plans can be feasible.

At first, venture capital investment was evaluated using the traditional DCF method. The Free Cash Flow to Firm (FCFF) value is 65,951,000 HUF (assuming a 10\% cost of capital), which can be used to calculate the value of the company by taking into account two stages of venture capital investment $(39,000,000$ HUF), so in this case, it is 26,951,000 HUF.

Table 2. Input parameters of the real option valuation

Source: own construction

\begin{tabular}{|l|c|c|}
\hline Input parameters & Variable & Values \\
\hline Underlying asset value (PV(FCFF)) & $\mathrm{S}$ & $65,951,000 \mathrm{HUF}$ \\
\hline $\begin{array}{l}\text { Exercise Price (venture capital } \\
\text { investment) }\end{array}$ & $\mathrm{X}$ & $\begin{array}{c}39,000,000 \mathrm{HUF}\left(\mathrm{X}_{1}=9,000,000 \mathrm{HUF},\right. \\
\left.\mathrm{X}_{2}=30,000,000 \mathrm{HUF}\right)\end{array}$ \\
\hline Time to expiration & $\mathrm{t}$ & 1.5 year \\
\hline Volatility & $\boldsymbol{\sigma}$ & $64.46 \%$ \\
\hline Risk-free interest rate & $\mathrm{r}$ & $2.5 \%$ \\
\hline
\end{tabular}

According to the parameters of Table 2, the call option value with Black-Scholes model is $33,641,000$ HUF that shows the embedded flexibility in the model that is equal to the difference between the call option value and FCFF value, so 6,690,000 HUF. 
The other frequently used real option evaluation method is the binomial pricing model that was also calculated in the case of the venture capital investment. The calculated parameters of the model can be seen in Table 3 .

Table 3. Calculated parameters of the binomial pricing model Source: own construction

\begin{tabular}{|l|c|c|}
\hline Parameters & Variables & Values \\
\hline Number of periods & $\Delta \mathrm{t}$ & 0.25 \\
\hline Upside parameter & $\mathrm{u}$ & 1.38 \\
\hline Downside parameter & $\mathrm{d}$ & 0.72 \\
\hline Risk-neutral probability & $\mathrm{q}$ & 0.46 \\
\hline
\end{tabular}

With the help of the input and the calculated parameters, the underlying asset values and the call option values were computed, then the two binomial trees were drawn (Figure 2 and 3). The first value in Figure 3 is the call option value that is equal to 32,837,370 HUF.

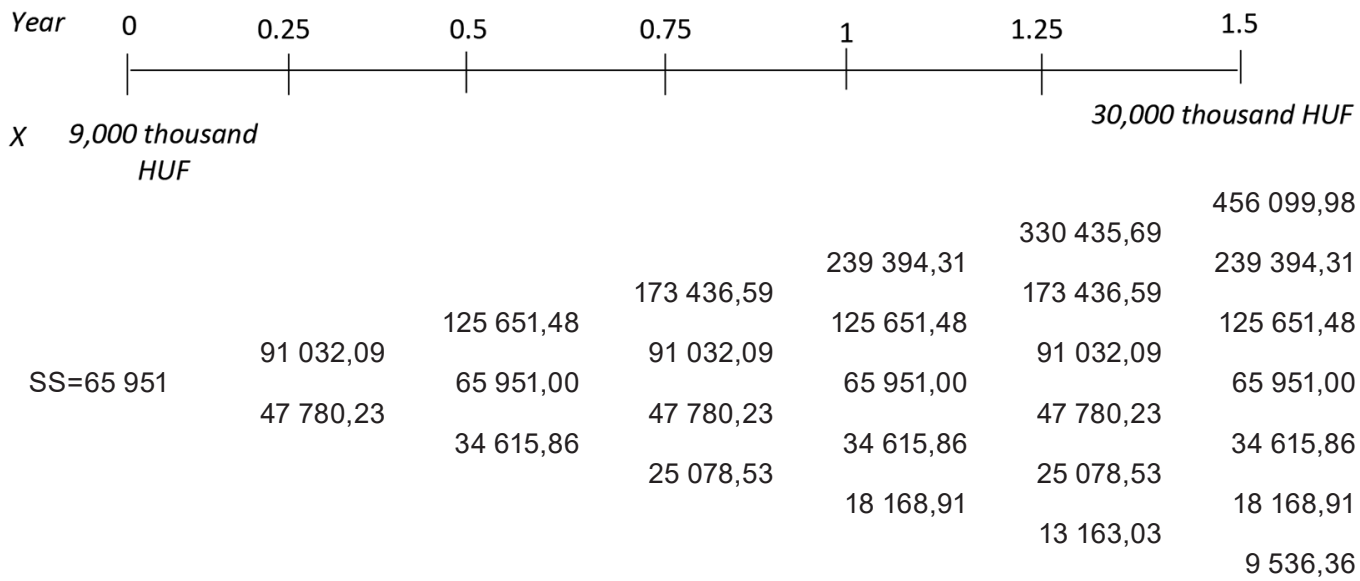

Figure 2: Binomial tree of the underlying asset (values in thousands HUF)

Source: Own construction

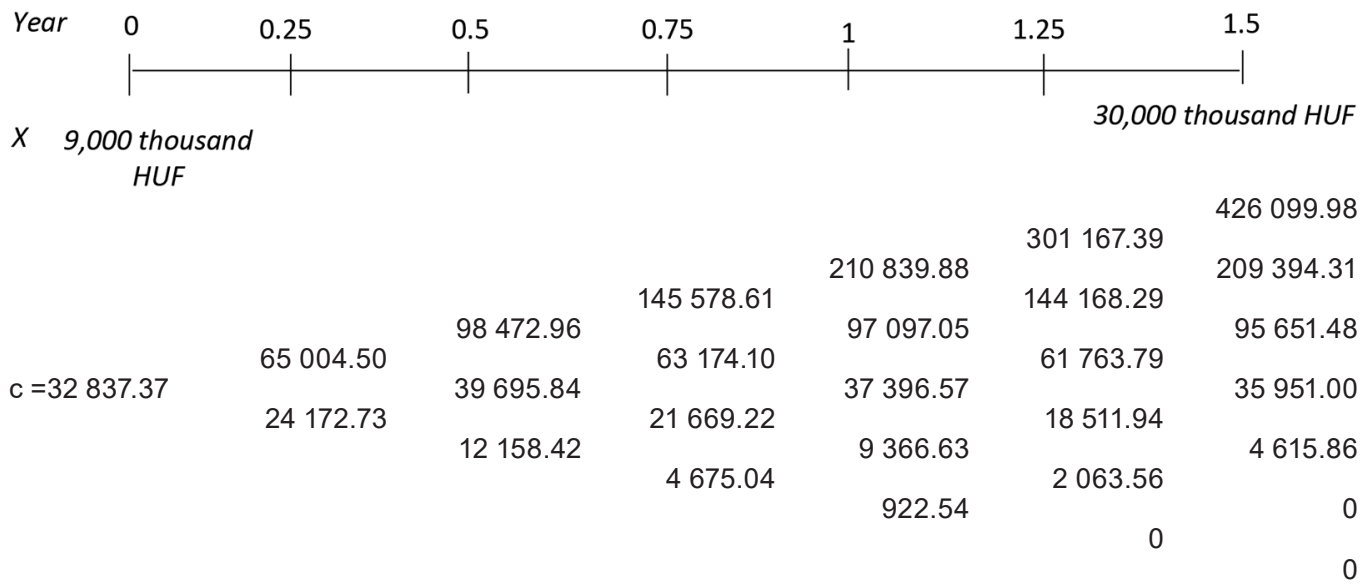

Figure 3: Binomial tree of the call option (values in thousand HUF)

Source: Own construction 
The result shows that the DCF method gave the lowest company value in the case of venture capital investment that is followed by the binomial pricing model value and the highest value was generated by the Black-Scholes model with 33,641,000 HUF (Table 4). The difference between the result of the DCF and option valuation methods shows the value creation of the uncertainty and the embedded strategic flexibility. The binomial option pricing model demonstrates a higher level of strategic flexibility as the literature review also certified staging advantages and value-creating role. When we would like to detect the effect of staging in the binomial pricing model, it can be assumed only one portion of venture capital investment that results in a lower option value after the calculation $(27,294,770 \mathrm{HUF})$. It emphasizes the importance of investment timing and staging investment.

Table 4. Result of the venture investment valuation

Source: Own construction

\begin{tabular}{|c|c|}
\hline Model & Company value \\
\hline DCF model (FCFF) & $26,951,000$ HUF \\
\hline Black-Scholes model & $33,641,000 \mathrm{HUF}$ \\
\hline Binomial pricing model & $32,837,370 \mathrm{HUF}$ \\
\hline
\end{tabular}

\section{CONCLUSION}

The paper focused on the evaluation of venture capital investments with the help of real option theory. The literature review showed that venture capital investments have the characteristics that require the application of real option logic and analyzing tool. Venture capital investments can be described with a high degree of uncertainty, partial irreversibility and these need to have active management. Staging serves as a control mechanism for venture capitalists because it provides a periodic reassessment of venture capital financing.

The most accepted evaluation methods, the Black-Scholes model and the binomial pricing model, were tested on venture capital investments in a Hungarian start-up company. The Black-Scholes model generated the highest option value with 33,641,000 HUF. The case study certified that real option valuation methods are more appropriate for evaluating venture capital investments and young, early-stage companies because of these high degrees of uncertainty and the strategic flexibility than the traditional valuation methods.

\section{ACKNOWLEDGMENT}

Supported by the ÚNKP-19-3 New National Excellence Program of the Ministry for Innovation and Technology.

\section{REFERENCES}

Adetunji, O., \& Owolabi, A. (2016). The Evolution of Real Options and its Applications in Management: A Review of Literature. The International Journal of Business and Management, 4(1) pp. 98-118.

Adler, R. W. (2000). Strategic Investment Decision Appraisal Techniques: The Old and the New. Business Horizons, 43(6) pp. 15-22. DOI: 10.1016/s0007-6813(00)80017-8

Bergemann, D., \& Hege, U. (2005). The Financing of Innovation: Learning and Stopping. $R \& D$ Journal of Economics, 36(4), 719-752. 
Black, F., \& Scholes, M. (1973). The Pricing of Option and Corporate Liabilities. Journal of Political Economy, 81(3) 637-654. DOI: 10.1086/260062

Boyer, M., Christoffersen, P., Lassere, P., \& Pavlov, A. D. (2003). Value Creation, Risk Management, and Real Options, Centre for Interuniversity Research and Analysis on Organisations [on-line]. CIRANO, CIRANO Burgundy Reports. 3. https://www.researchgate.net/publication/4816345_Value_creation_risk_management_and_real_options (2018.10.02).

Brealey, R.-Myers, S. (2005). Fundamentals of Corporate Finance. 5th Edition. McGraw-Hill.

Breen, R. (1991). The Accelerated Binomial Option Pricing Model. The Journal of Financial and Quantitative Analysis, 26(2), 153-164. DOI:10.2307/2331262

Bygrave, W. D., \& Timmons, J. A. (1992). Venture Capital at the Crossroads', Boston: Harvard Business School Press.

Bygrave, W., Fast, N., Khoylian, R., Vincent, L., \& Yue, W. (1989). Early Rates of Return of 131 Venture Capital Funds Started 1978-1984. Journal of Business Venturing, 4(2), 93-105. DOI: 10.1016/0883-9026(89)90024-4

Carvalho, A. G., Calomiris, C., \& Matos, J. A. (2005). Venture Capital as Human Resource Management. NBER Working Paper Series, National Bureau of Economic Research. Cambridge, 2005 May.

Cassar, G. (2004). The Financing of Business Start-ups. Journal of Business Venturing, 19(2) 261283. DOI: 10.1016/s0883-9026(03)00029-6

Chotigeat, T., Pandey, I. M., \& Kim, D. J. (1997). Venture Capital Evaluation in Emerging Markets. Multinational Business Review, 5(2), 54-62.

Copeland, T. E., \& Antikarov, V. (2001). Real Options: A Practitioner's Guide. New York, Texere, $372 \mathrm{p}$.

Cox, J., Ross, S., \&Rubinstein, M. (1979): Option pricing: A Simplified Approach. Journal of Financial Economics. 7(3), 229-263.

Csapi V. (2018): A reálopciók első 40 éve, Vezetéstudomány, 49(9), 34-45. DOI: 10.14267/veztud.2018.09.03

Cumming, D. J., \& MacIntosh, J. G. (2001). Venture capital investment duration in Canada and the United States. Journal of Multinational Financial Management, 11(4-5), 445-463. DOI:10.1016/s1042-444x(01)00034-2

Dahiya, S., \& Ray, K. (2012). Staged Investments in Entrepreneurial Financing. Journal of Corporate Finance, 18(5) 1193-1216. DOI: 10.1016/j.jcorpfin.2012.07.002

Davis, M., Schachermayer, W., \& Tompkins, R. G. (2004). The Evaluation of Venture Capital as an Instalment Option: Valuing Real Options Using Real Options. In: Dangl T., Kopel M., Kürsten W. (eds) Real Options, ZfB-Ergänzungshefte: Gabler Verlag, Wiesbaden pp. 77-96.

Fried, V. H., \& Hisrich, R. D. (1994). Toward a Model of Venture Capital Investment Decision Making. Financial Management, 23(3), pp. 28-37. DOI: 10.2307/3665619

Gerasymenko, V., \& Arthurs, J. D. (2014). New insights into venture capitalists' activity: IPO and time-to-exit forecast as antecedents of their post-investment involvement. Journal of Business Venturing, 29(3), 405-420. DOI: 10.1016/j.jbusvent.2013.06.003

Gompers, P. A. (1995). Optimal Investment, Monitoring, and the Staging of Venture Capital. The Journal of Finance, 50(5), 1461-1489. DOI:10.2307/2329323

Gompers, P., \& Lerner, J. (1999): The Venture Capital Cycle. Cambridge: The MIT Press.

Gong, P., He, Z., \& Meng, J. (2006). Time-dependent Volatility Multi-stage Compound Reap Option Model and Application. Journal of Industrial Engineering and Engineering Management, 1-14.

Hartmann, M. (2006). Realoptionen als Bewertungsinstrument für frühe Phasen der Forschung und Entwicklung in der pharmazeutischen Industrie. Genehmigte Dissertation. Berlin, (Technische Universität Berlin), 256 p. 
Hege, U., Schweinbacher, A., \& Palomino, F. (2009). Venture Capital Performance: The Disparity Between Europe and the United States. Finance, 30(1), 7-50. DOI: 10.2139/ssrn.482322

Herder, P. M., de Joode, J., Ligtvoet, A., Schenk, S., \& Taneja, P. (2011). Buying real options. Valuing uncertainty in infrastructure planning. Futures, 43(4), 961-969. DOI: 10.1016/j.futures.2011.06.005

Hommel, U., \& Pritsch G. (1999). Marktorientierte Investitionsbewertung Mit Dem Realoptionsansatz. Finanzmarkt und Portfoliomanagement, 13(2), 115-144.

Hsu, D. H. (2002). What Do Entrepreneurs Pay for Venture Capital Affiliation? Hsu, David H., What Do Entrepreneurs Pay for Venture Capital Affiliation? University of Pennsylvania Wharton School Working Paper. Available at SSRN: https://ssrn.com/abstract=350380 or http://dx.doi.org/10.2139/ssrn.350380

Huang, Y., \& Chou, S. (2006). Valuation of Minimum Revenue Guarantee and the Option to Abandon in BOT Infrastructure Projects. Construction Management and Economics, 24(4), 379-389. DOI: 10.1080/01446190500434997

Jägle, A. J. (1999). Shareholder Value, Real Options, and Innovation in Technology Intensive Companies. R\&D Management, 29(3) 271-288. DOI: 10.1111/1467-9310.00136

Karsai, J. (2006). Kockázati tőke európai szemmel. Közgazdasági Szemle, LIII, 1023-1051.

Karsai, J., Wright, M. Dudzinski, Z., \& Morovic, J. (1998). Screening and Valuing Venture Capital Investments: Evidence from Hungary, Poland and Slovakia, Entrepreneurship and Regional Development, 10, 203-224. DOI: 10.1080/08985629800000012

Ko, C., Lin. T. T., \& Yang, C. (2011). The Venture Capital Entry Model on Game Options with Jump-diffusion Process. International Journal of Production Economics, 134, 87-94. DOI: 10.1016/j.ijpe.2011.02.016

Kogut, B., \& Kulatilaka, N. (2001). Capabilities as Real Options. Organization Science, 12(6), 744-758. DOI: $10.1287 /$ orsc.12.6.744.10082

Landier, A. (2002). Startup Financing: From Banks to Venture Capital. Working Paper - Massachusetts Institute of Technology.

Landström, H. (2007). Handbook of Research on Venture Capital. Cheltenham, U.K.: Edward Elgar Publishing Ltd.

Lee, J. (2018). Venture Capital and Firm Performance. The Korean Experience in a Global Perspective. New York: Routledge.

Li, Y. (2008). Duration Analysis of Venture Capital Staging: A Real Options Perspective. Journal of Business Venturing, 23(5), 497-512. DOI: 10.1016/j.jbusvent.2007.10.004

Lorenz, A. (1989). Venture Capital Today. London: Woodhead Faulkner.

Luehrman, T. A. (1998). Investment Opportunities as Real Options: Getting Started on the Numbers. Harvard Business Review, 76(7-8), 51-67.

Lukas, E., Mölls, S., \& Welling, A. (2016). Venture capital, staged financing and optimal funding policies under uncertainty. European Journal of Operational Research, 250(1), 305-313. DOI: 10.1016/j.ejor.2015.10.051

Majd, S., \& Pindyck, R. (1987). Time to Build, Option Value, And Investment Decisions. Journal of Financial Economics, 18(1) 7-27. DOI: 10.3386/w1654

Maula, M. V. J. (2007). Corporate Venture Capital as a Strategic Tool for Corporations, In:

Metrick, A., \& Yasuda, A. (2011). Venture Capital and the Finance of Innovation. Hoboken, New Jersey (USA): John Wiley \& Sons

Miltersen, K., \& S. Schwart, E. (2004). R\&D Investments with Competitive Interactions. Review of Finance, 8(3), 355-401. DOI: 10.3386/w10258

Park, C. S., \& Herath, H. S. B. (2000). Exploiting Uncertainty-Investment Opportunities as Real Options: A New Way of Thinking in Engineering Economics. The Engineering Economist, 45(1), 1-36. DOI: 10.1080/00137910008967534 
Pennings, E., \& Lint, O. (1997). The Option Value of Advanced R\&D. European Journal of Operational Research, 103(1), 83-94.

Pless, J., \& Arent, D. J., Logan, J., Cochran, J., Zinaman, O. (2016). Quantifying the Value of Investing in Distributed Natural Gas and Renewable Electricity Systems as Complements: Applications of Discounted Cash Flow and Real Options Analysis with Stochastic Inputs. Energy Policy, 97 378-390.

Pritsch, G. (2000). Realoptionen als Controlling-Instrument: Das Beispiel Pharmazeutische Forschung und Entwicklung. Wiesbaden: Deutscher Universitätsverlag;

Rodrigues, A., \& Armada, M. (2007): The Valuation of Modular Projects: A Real Options Approach to the Value of Splitting. Global Finance Journal, 18(2), 205-227. DOI: 10.1016/j. gfj.2006.10.002

Rosenbusch, N., \& Brinckmann, J., Müller, V. (2013). Does Acquiring Venture Capital Pay Off for the Funded Firms? A Meta-analysis on the Relationship Between Venture Capital Investment and Funded Firm Financial Performance. Journal of Business Venturing, 28(3), 335-353. DOI: 10.1016/j.jbusvent.2012.04.002

Rózsa A. (2004). Stratégiai beruházások reálopciós megközelítése. Vezetéstudomány, 35(2), 5361.

Rózsa A. (2007). A reálopciók lehetőségei és korlátai a stratégiai beruházások értékelésében. Szakmai füzetek. 19, 50-63.

Sahlman, W. A. (1990). The Structure and Governance of Venture Capital Organizations. Journal of Financial Economics, 27, 473-521. DOI: 10.1016/0304-405x(90)90065-8

Sahlman, W. A. (1993). Aspects of Financial Contracting in Venture Capital. In: Chew, D. H. (ed.): The New Corporate Finance: Where Theory Meets Practice. New York: McGrawHill, p. 229-242.

Schulmerich, M. (2010). Real Options Valuation: The Importance of Interest Rate Modelling in Theory and Practice. 2nd Edition, Berlin, Springer, 389 p.

Scialdone, P. (2007). Valuing Managerial Flexibility: Challenges and Opportunities of the Real Option Approach in Practice. Göttingen, Cuvillier Verlag, 309 p.

Seppa, T. J., \& Laamanen, T. (2001). Valuation of Venture Capital Investments: Empirical Evidence. $R$ and D Management, 31(2), pp. 215-230. DOI:10.1111/1467-9310.00211

Smith, J. A., \& Cordina, R. (2014). The Role of Accounting in High-Technology Investments. The British Accounting Review, 46(3), 309-322. DOI: 10.1016/j.bar.2014.03.002

Smith, J. E., \& McCardle, K. F. (1999). Options in the Real World: Lessons Learned in Evaluating Oil and Gas Investments. Operations Research. 47(1), 1-15. DOI: 10.1287/opre.47.1.1

Steier, L., Greenwood, R. (1995). Venture Capitalist Relationships in the Deal Structuring and Post-Investment Stages of New Firm Creation, Journal of Management Studies, 32(3), 337357. DOI: 10.1111/j.1467-6486.1995.tb00779.x

Takács, A. (2014). The Relationship between Appraised Company Values and Future Stock Prices in the International Banking Sector. International Research Journal of Finance and Economics, 9(118), 113-123. DOI: 10.7176/rjfa/10-14-09

Triantis, A., \& Borison, A. (2001). Real Options: State of The Practice. Journal of Applied Corporate Finance, 14(2), 8-24.

Trigeorgis, L. (1993). The Nature of Option Interactions and The Valuation of Investments with Multiple Options. Journal of Financial and Quantitative Analysis, 28(1), 1-20. DOI: 10.2307/2331148

Trigeorgis, L. (1996). Real Options: Managerial Flexibility and Strategy in Resource Allocation. Cambridge, MIT Press, 427 p.

Tyebjee, T., \& Bruno, A. (1984). A Model of Venture Capitalist Investment Activity, Management Science, 30, 1051-1066. DOI: 10.1287/mnsc.30.9.1051 
Wang, K., \& Zhou, Y. (2006). Equilibrium Real Options Exercise Strategies with Multiple Players: The Case of Real Estate Markets. Real Estate Economics, 34(1), 1-49. DOI: 10.1111/j.15406229.2006.00158.x

Willner, R. (1995). Valuing Startup Venture Growth Options. In: Trigeorgis, L. (1996) (ed.): Real Options in Capital Investment - Models, Strategies and Applications, Westport: Praeger. 221.-239.

Wright, M., Lockett, A., Pruthi, S., Manigart, S., Sapienza, H., Desbrieres, P., \& Hommel, U. (2004). Venture Capital Investors, Capital Markets, Valuation, and Information: US, Europe, and Asia. Journal of International Entrepreneurship, 2(4), pp. 305-326. DOI: 10.1007/ s10843-004-0131-0

Wright, M., \& Robbie, K. (1996). Venture Capitalist and Unquoted Equity Investment Appraisal. Accounting and Business Research, 26(1), 153-168. DOI: 10.1080/00014788.1996.9729506

Yeo, K. T., \& Qui, F. (2003). The Value of Managerial Flexibility - a Real Option Approach to Investment Evaluation. International Journal of Project Management, 21(4), 243-250. DOI: 10.1016/s0263-7863(02)00025-x 